\title{
Origin Of Calcareous Sediments in the Holocene Pigeon Creek Tidal Lagoon and Tidal Delta, San Salvador Island, Bahamas
}

\author{
B. A. Welle, A. C. Hirsch, L. E. Davis \\ Department of Geology \\ College of St. Benedict / St. John's University \\ Collegeville, Minnesota 56321 USA
A. C. Johnson, G. J. Hunt, and R. L. Eves
Department of Geology
Southern Utah University
Cedar City, Utah 84720 USA

Received: February 17, $2004 \quad$ Accepted: March 15, 2004

\begin{abstract}
A sedimentological survey of the southwest arm of the Holocene Pigeon Creek tidal lagoon on San Salvador Island, Bahamas was conducted to determine the origin and distribution of calcareous sediments. Transect surveys, surface samples, and sediment cores were collected and examined to determine the abundance and distribution of sediments and sediment producers in the lagoon and associated tidal delta. The study area has three regions: an extensive tidal to shallow, subtidal flat; a tidal channel near the entrance to the lagoon; and a lobate, ebbdominated tidal delta. Tidal flat sediments were extensively bioturbated and heavily rooted by Thalassia testudinum. Tidal flat sediments ranged from coarse, calcareous sand to calcareous muds, and were rich in gastropod shells, foraminifera, calcareous algae, and pelletal calcareous mud. The tidal flat sediments are assigned to a pellet-lime wackestone to muddy lime packstone lithofacies. Calcareous green algae are the primary producers of calcareous sediments in the lagoon with species of Halimeda and Penicillus being the dominant genera. Surface samples taken from the coarse channel lag of the tidal channel consisted primarily of whole and fragmented bivalves and gastropods. Most of the bivalves were oriented convex upward. Surface samples taken from ripples, mega-ripples, and sand waves of the tidal delta are dominated by well-sorted, well-rounded, and polished sand-size grains (1-2 $\mathrm{mm}$ in diameter). This sediment was dominated by bioclasts (bivalves, gastropods, calcareous algae, foraminifera) and minor ooids. Sediments of the tidal channel and tidal delta are assigned to a lime packstone to grainstone lithofacies. The coarsest fraction $(>2 \mathrm{~mm})$ accumulated on the lee slopes and troughs of large, tidal and wave produced ripples. Ripples for both ebb- and flood tides are strongly asymmetrical, but symmetrical ripples are common, indicating that significant migration of the tidal delta does not occur during normal tidal events. A low energy, shallowing upward cycle is well illustrated in the lagoon, and the presence of a depaurperate biofacies and heavily bioturbated and rooted lithofacies typify a carbonate lagoon depositional environment.
\end{abstract}

I. PURPOSE

This project was part of a larger survey of the flora and fauna of the Holocene Pigeon Creek tidal lagoon on San Salvador Island, Bahamas and conducted by undergraduate students and faculty during a 1-week course on the geology and biology of San Salvador Island. Our purpose was to characterize the sediment within the Pigeon Creek tidal lagoon.

\section{STUDY AREA}

San Salvador is one of 700 islands

in the north-south trending Bahamas 
Archipelago (Fig. 1) located along the edge of the continental margin east of Florida. The island is approximately midway along the easternmost margin of the archipelago at $24^{\circ} 3^{\prime} \mathrm{N}$ latitude and $74^{\circ} 30^{\prime} \mathrm{W}$ longitude. Deep waters of the Atlantic, exceeding $4,000 \mathrm{~m}$, surround San Salvador. The island has a surface area of $94.9 \mathrm{~km}^{2}$, most of which consists of shallow, brackish to hypersaline lakes occupying the low interdune areas of series of arcuate, eolian dune ridges. Cliffs of eroding eolianite form prominent headlands with intervening fineto medium-grained carbonate sand beaches and Holocene beach rock. Fringing reefs surround most of the island [1].

The two arms of Pigeon Creek lagoon are located along the southeastern margin of San Salvador (Fig. 2). A north trending arm extends for approximately $6 \mathrm{~km}$ with a maximum width of $1.5 \mathrm{~km}$. The northern arm is bounded on the east by poorly consolidated eolian sands and on the west by Pleistocene carbonate rock [2]. A smaller, southwest-trending arm, and the focus of this study, is approximately $3 \mathrm{~km}$ long with a maximum width of $1 \mathrm{~km}$. The southwestern arm of the lagoon narrows to approximately $125 \mathrm{~m}$ before joining the larger northern arm. Red mangroves (Rhizophora mangle) surround the margins of both arms of the lagoon. A tidal inlet forms a connection between the two arms of the lagoon and the open marine waters of Snow Bay. An ebb tide delta extends from the mouth of the tidal inlet seaward into Snow Bay.

\section{INTRODUCTION}

The earliest study of carbonate rock and sediment extends back 125 years to the work of Sorby [3]. During the 1950s, 60s and 70 s, sedimentologists began to focus on the origin of modern carbonate muds and sands [4-16]. Flügel [17] attributed the origin of carbonate mud (micrite) to six sources: (1) inorganic chemical precipitation of $\mathrm{CaCO}_{3}$ (2) bacterial activity and decomposition of organic substances composed primarily of $\mathrm{CaCO}_{3}$ (3) plant assimilation and algal activity resulting in the precipitation of $\mathrm{CaCO}_{3}$ (4) submicroscopic algal fragments of $\mathrm{CaCO}_{3}(5)$ disintegration of $\mathrm{CaCO}_{3}$ hard parts of invertebrates and (6) borings of endolithic algae and invertebrates into calcareous exoskeletons.

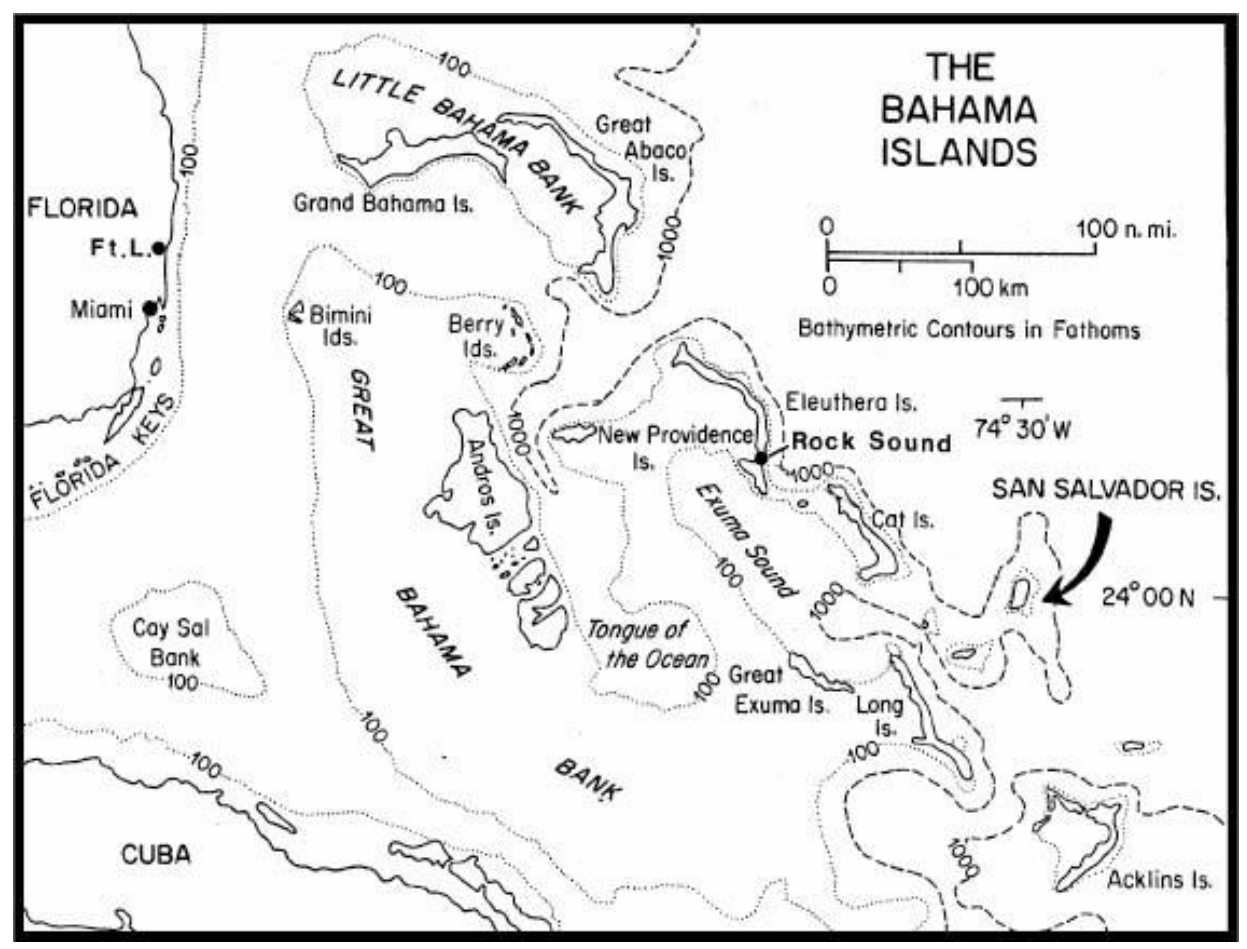

Figure 1. Location map of the Bahamas Archipelago. Adapted from Curran (1985) [1]. 
During this study, there was no evidence of $\mathrm{CaCO}_{3}$ precipitation, although studies of this phenomenon, known as "whitings", have been conducted elsewhere on the Bahamian Platform [18]. Bacterial activity (stromatolites) is a common feature in the higher salinity waters of the northern arm of the lagoon, but none was observed in the study area. Endolithic algae borings are relatively common features on a variety of invertebrate shells, particularly bivalves, but are not considered to be a major form of carbonate mud production in the lagoon. The growth of calcareous algae and their ultimate chemical and mechanical breakdown, plus the disintegration of the skeletal components of various marine invertebrates (molluscs, echinoderms, foraminifera) are consider to be the major contributors to carbonate mud production, as well as the production of larger carbonate grains, in the southwestern arm of Pigeon Creek lagoon. Calcareous green algae are the primary producers of calcareous sediments in the lagoon with species of Halimeda and Penicillus being dominant.

\section{CARBONATE LITHOFACIES}

a. Pelletal_Lime Wackstone to Muddy Packstone Lithofacies

The majority of sediments in the Pigeon Creek lagoon are deposited in the pelletal, lime wackestone to muddy packstone lithofacies. Carbonate mud (micrite) and fecal pellets make up $90+\%$ of the sediment in the lagoon. The majority of carbonate mud is aragonitic, being derived from the disintegration of calcareous algae, particularly species of Halimeda and Penicillus, and to a lesser extent species of Udotea, Rhipocephalus, Avrainvillea, and Acetabularia (Fig. 3). Abrasion and breakdown of other calcareous organisms, such as foraminifera, echinoderms and molluscs, likely contribute to $<10 \%$ of the carbonate mud. Pelletal grains, 50-200 microns in size, are composed of micrite and are being produced primarily by the crustacean Callianassa, although some pellets are produced by gastropods, chiefly species of Cerithium.

Less than $10 \%$ of this lithofacies consists of sand-size grains $(1 / 16-2 \mathrm{~mm})$. The sand-size component consist primarily

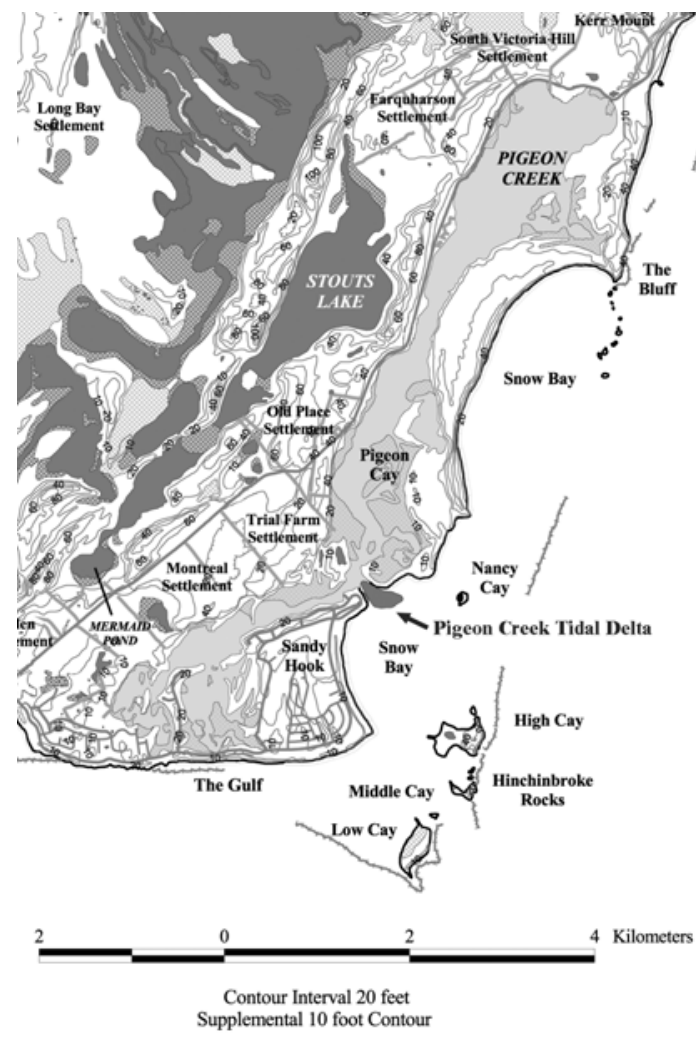

Figure 2. Location map of the southwestern portion of San Salvador Island, Bahamas, showing Pigeon Creek Lagoon (shaded light gray). Adapted from the Gerace Research Center web site http://www.geraceresearch center.com/.

of whole and fragmented foraminifera, Halimeda plates, and to a lesser extent, abraded and broken molluscs and echinoderms. Less than $1 \%$ of the carbonate grains are $>2 \mathrm{~mm}$, and consist of whole and broken gastropods (principally Cerithium sp., Tricolia sp. and Strombus gigas), bivalves (principally Chiore sp., Lucina sp., Laevicardium sp., and Nucula sp.), echinoderms (principally Clypeaster rosaceus, Leodia sexiesperforata, and Diadema antillarum), and cnidarians (principally Manicina areolata and Oculina diffusa).

Mounds produced by burrowing of Callianassa are common features over large areas of this lithofacies (Fig. 4). In areas of the lagoon where turtle grass (Thalassia testudinum) is limited, Callianassa mounds produce a puscular appearance on the sediment surface at low tide. 


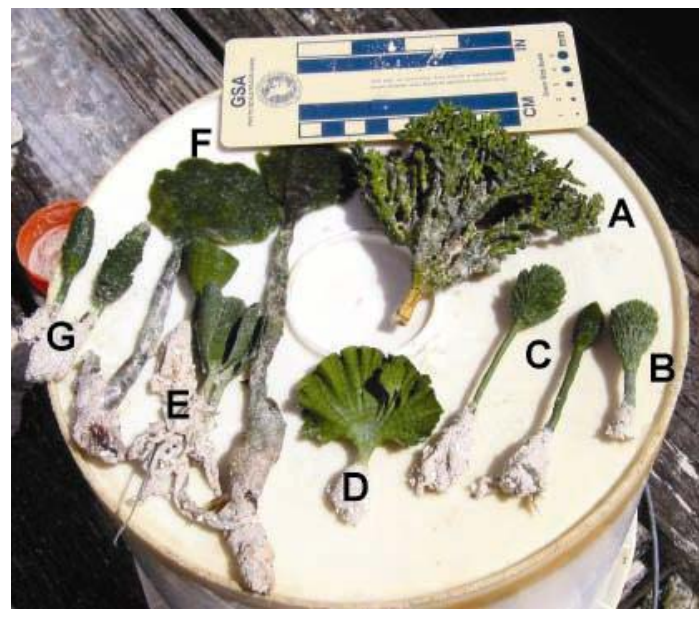

Figure 3. Common calcareous algae collected from Pigeon Creek lagoon: (A) Halimeda incrassate; (B) Penicillus dumetrosus; (C) P. pyriformis; (D) Udotea flabellum; (E) U. cyathiformis; (F) Avrainvillea sp; and (G) Rhipocephalus brevifolius.

Sediment in the pelletal, lime mud lithofacies is heavily rooted by Thalassia testudinum. The blades of $T$. testudinum are commonly encrusted with foraminifera. Dense stands of $T$. testudinum serve to baffle currents, causing the deposition and stabilization of the carbonate mud, thus reducing the erosive aspects of tidal currents and wind-generated waves (Fig. 5). Ball, et al. [19] noted that the stabilizing effects of Thalassia testudinum are clearly demonstrated when hurricanes strike. At localities around San Salvador Island, very little erosion occurs in the turtle grass areas, while turtle grass-free areas of lime sand and reefs experience considerable erosion and damage.

Near the mouth of the lagoon, tidal energy is much higher, and a narrow (30-40 $\mathrm{m}), 3 \mathrm{~m}$ deep, erosive tidal channel has incised into the pelletal, lime mud lithofacies. Tidal currents erode and undercut the carbonate mud below the $T$. testudinum rooted zone resulting in the creation of large blocks of root-bounded carbonate mud, which tumble into the tidal channel and remain intact for a considerable length of time (Fig. 6).

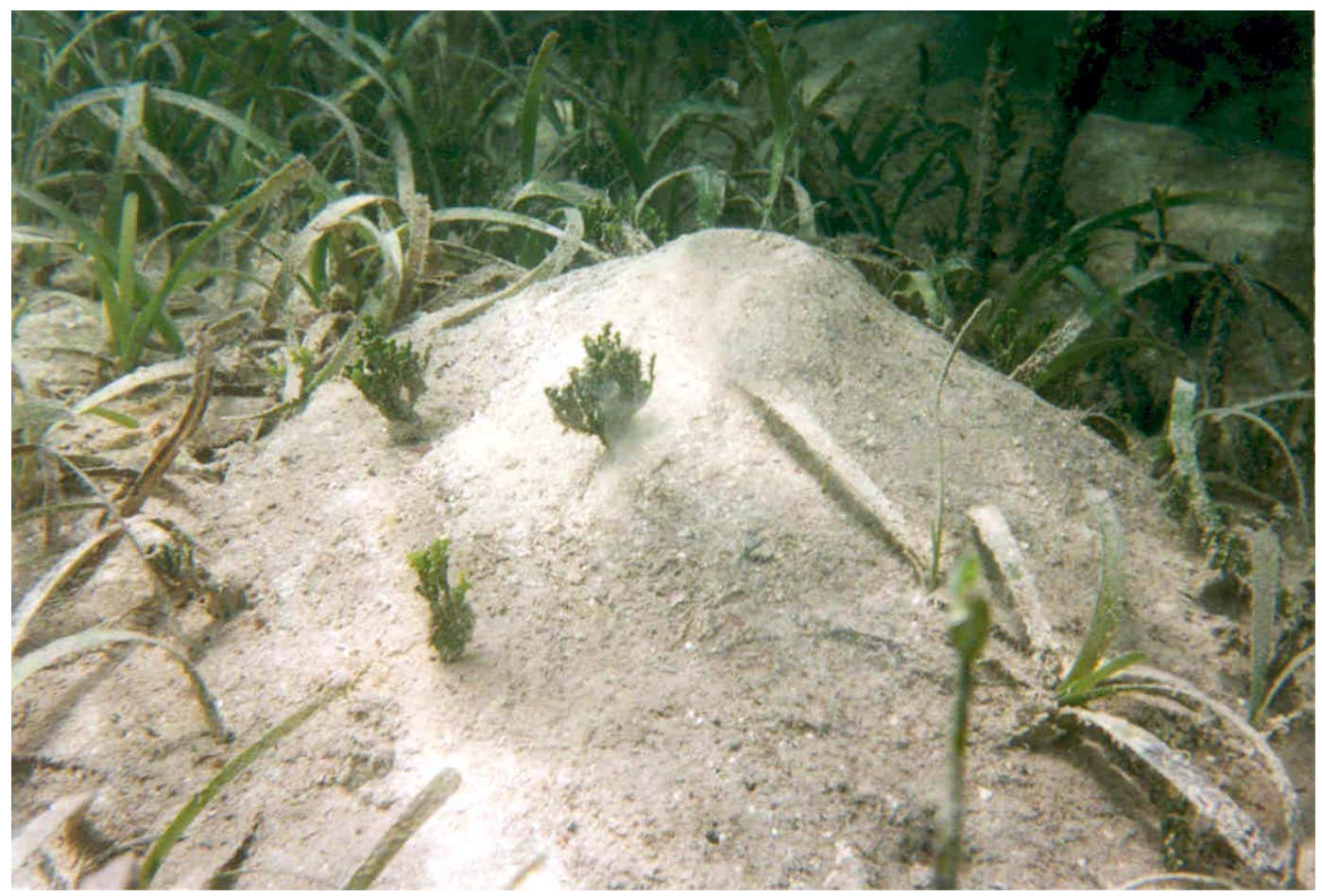

Figure 4. Mound of calcareous sediment produced by the burrowing shrimp Callianassa $s p$. Several Halimdeda incrassate are rooted on the mound margin, while Thalassia testudinum grow thickly between mounds. [Full color versions of this and other figures can be seen at www.ajur.uni.edu, the journal website-Editor.] 


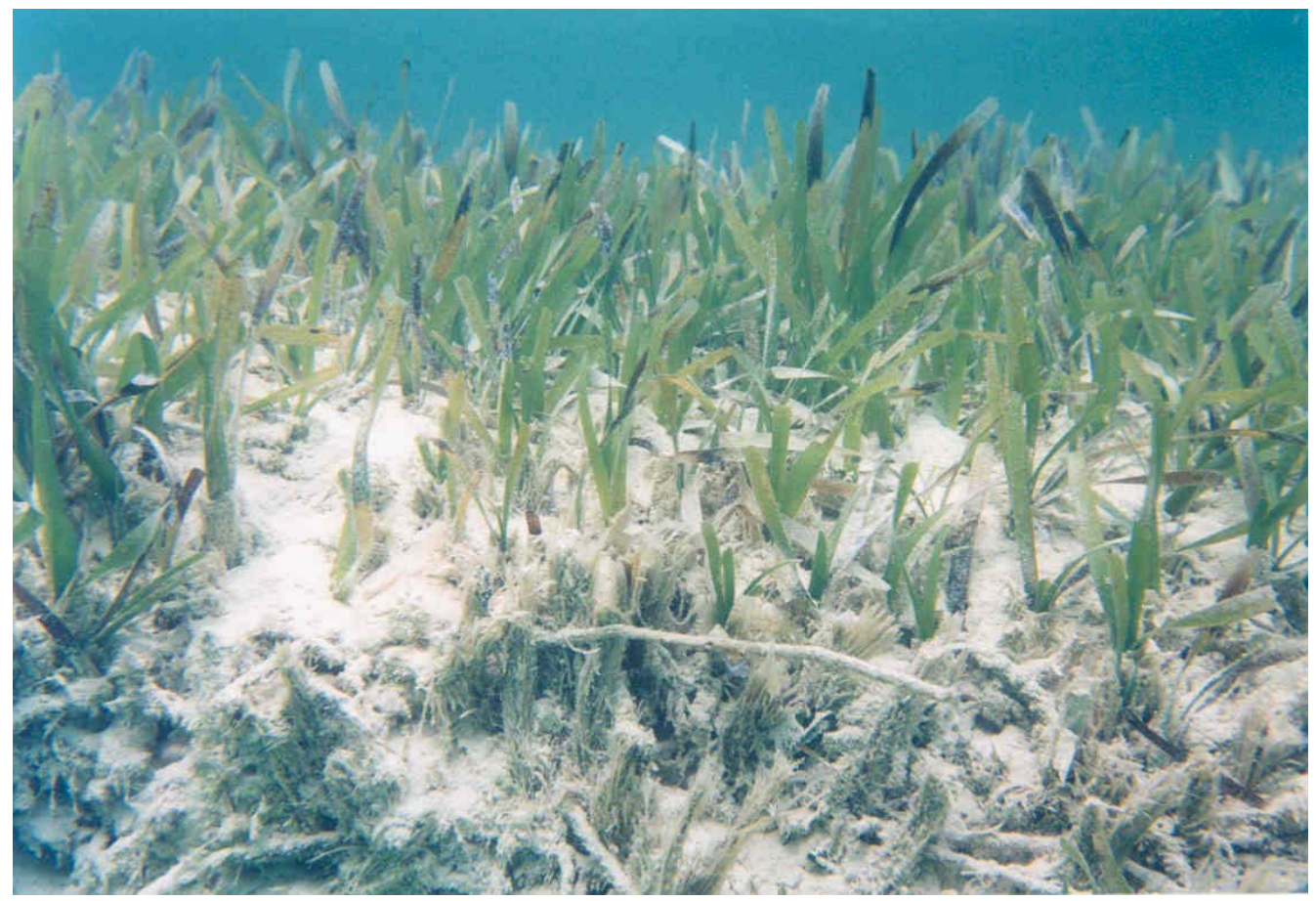

Figure 5. Dense stand of Thalassia testudinum, which baffles tidal and wave currents thereby trapping and binding carbonate sediments.

\section{b. Lime Packstone to Grainstone Lithofacies}

Due to the difficulty of pushing a sediment corer into the sediment of this lithofacies, specific grain size analysis and species composition for the lithofacies were not conducted. The lithofacies characterization is based upon surface grab samples.

Sediments within the tidal channel and the active, ebb tidal delta are deposited in the lime packstone to grainstone lithofacies. These sediments are highly abraded, well-winnowed sands $(1 / 16-2 \mathrm{~mm})$ composed almost entirely of grains of skeletal origin, with only minor mud accumulating in low-lying areas in the shadow of tidal current produced ripples. Broken and abraded Halimeda plates and Goniolithon branches, whole and broken bivalves and gastropods, and foraminifera dominate this skeletal sand. The very minor occurrence of ooids is considered to be of relic origin. Bioclasts $>2 \mathrm{~mm}$ are dominated by gastropods, bivalves, calcareous algae, and foraminifera.

The coarsest fraction, bioclasts >
$2 \mathrm{~mm}$, in this lithofacies occur primarily as a lag in the tidal channel. In the tidal channel, both ebb and flood currents can attain a velocity of $1 \mathrm{~m} / \mathrm{sec}$. Strong tidal currents remove all but the coarsest fraction of skeletal material from the tidal channel. Siltand clay-size carbonate is carried to the distal end of the tidal delta and beyond. The distal end of the tidal delta has been stabilized by $T$. testudinum, which serve to baffle the waning tidal currents allowing finer carbonates to settle and accumulate. Much of the sand-size $(1 / 16-2 \mathrm{~mm})$ carbonate grains, and the principal area of lime grapestone lithofacies distribution, accumulate between the seaward end of the tidal channel and the distal edge of the tidal delta stabilized by $T$. testudinum. The surface of this area is characterized by ripples with wave heights of $8-10 \mathrm{~cm}$ and wave lengths of $1-1.5 \mathrm{~m}$. Ripples are strongly asymmetrical during the ebb tide, whereas during the flood tide the ripples tend to be symmetrical. Repetitive transition from asymmetrical to symmetrical ripples suggests that significant migration of the tidal delta does not occur during normal tidal events. 


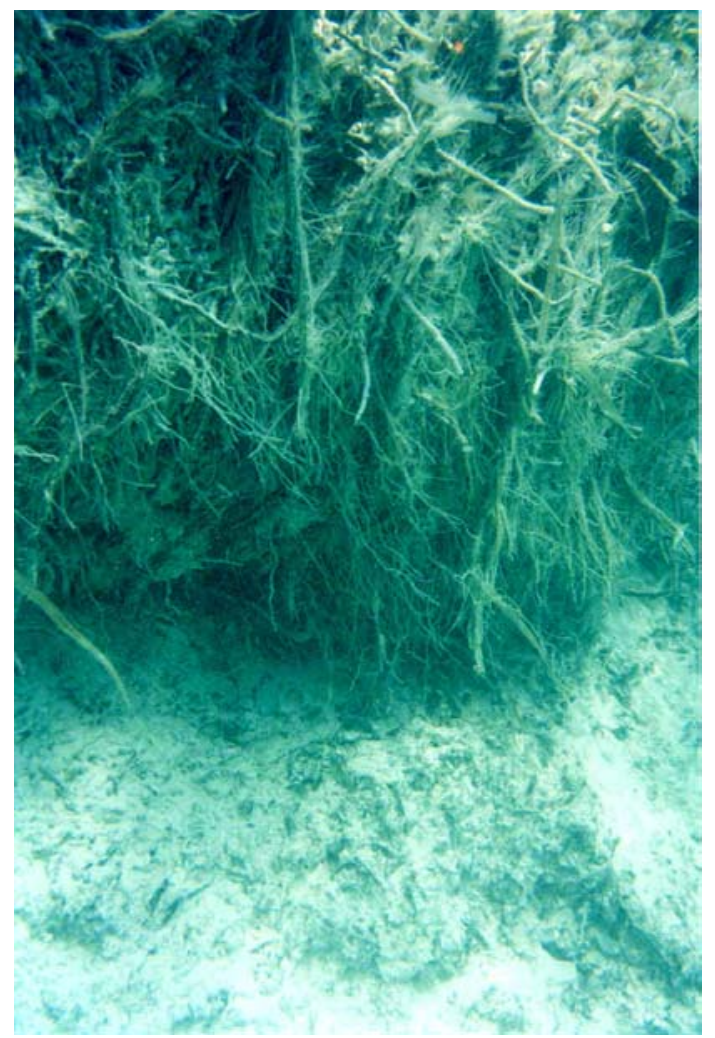

Figure 6. Roots of Thalassia testudinum can extend downward as much as $1-1.5$ meters, but below the rooted zone, strong tidal currents in the tidal channel near the lagoon entrance undercut the carbonate sediment. Eventually, large blocks of rooted carbonate tumble into the tidal channel.

\section{DISCUSSION}

In modern settings, lagoons are defined as partially enclosed water bodies with only a relatively small or narrow connection to the sea. Typically, lagoons are also relatively shallow, although some lagoons associated with coral atolls may have water depths exceeding 70 meters. Pre-Holocene lagoons are more loosely defined as low-energy, shallow-water regions with a demonstrable seaward barrier [20]. Of course, this same characterization could be made for pre-Holocene bays and restricted shelves, therefore recognition of ancient carbonate lagoons can be a more daunting task, especially one of the size of the Pigeon Creek lagoon. According to Enos [20, p. 268], no single criterion is diagnostic for environments as diverse as restricted shelves, bays, and lagoons.

Lithologically, lagoons can be characterized by a low energy, shallowing upward cycle consisting of basal bioclastic packstone to grainstone grading into a bioturbated, mudstone-wackestone-muddy packstone lithofacies, with an impoverished biota and, capped by supratidal and/or eolian carbonate deposits [20]. Eventually, one can expect to see a completed shallowing upward cycle in the Pigeon Creek lagoon. In the absence of well-defined sequences or cycles, recognition of a biofacies with a depaurperate biota coupled with a heavily bioturbated and rooted lithofacies may be the single most important characteristics for distinguishing a lagoonal depositional environment. This latter characteristic typifies the Pigeon Creek lagoon.

It was not the purpose of this report to measure the sedimentation rate within the Pigeon Creek lagoon, but in a study by Neumann and Land [16] of carbonate sediment accumulations in the Bight of Abaco, Bahmas a minimum sedimentation rate was determined to be $120 \mathrm{~mm} / 10^{3}$. Neuman and Land also demonstrated that the volume of carbonate sediment derived from the breakdown of calcareous algae (Halimeda, Penicillus, Rhipocephalus, and Udotea) was more than adequate to produce this rate of sedimentation. Stockman, et al. [11] also showed that "standing crops" of calcareous algae were $50 \%$ higher in the well-protected, low energy Florida Bay, than within the less protected inner Florida reef track. A study by Goodell and Garman [21] calculated the rate of subsidence of the Bahamian Platform at 38 $\mathrm{mm} / 10^{3}$ years. Pigeon Creek lagoon is very well protected with a large "standing crop" of calcareous algae making the lagoon a highly productive and efficient "carbonate factory". Based on the data presented by Neuman and Land [16] on annual carbonate production elsewhere on the Bahamian platform, and the rate of subsidence of the platform [21], it is easy to conclude that the Pigeon Creek lagoon will eventually complete a shallowing-upward cycle with a capping supratidal facies. The very distal margins of the lagoon are already near this point, where water depths, even at high tide, are 
measured in a few centimeters; salinities are greatly elevated (>68 ppt); and the faunal diversity is essentially 1 or 2 species of gastropods grazing on an algal mat.

The ease of access and relatively small size of the southwest are of Pigeon Creek lagoon, make it an ideal locality for studying a modern analog of carbonate lagoon deposition. Deeper cores, taken from the distal portions of the lagoon, are needed to demonstrate the suspected classic shallowing upward cycle of lagoon deposition.

\section{ACKNOWLEGEMENTS}

The authors would like to acknowledge the support of the Gerace Research Center and the following CSB/SJU and SUU students and faculty: Nick Boisen, Ann Christianson, David DeGrio, Zachary Faber, Kelly Fox, Gina Lux, Will Gorrilla, Lori McDonald, Joel Paulson, Kristi Strandberg, Kathryn Thompson, Dr. Gordon Brown and Dr. William Lamberts.

\section{REFERENCES}

1. Curran, H.A., 1985. Introduction to the geology of the Bahamas and San Salvador Island with an overflight guide, in, Curran, H.A. (ed), Pleistocene and Holocene Carbonate Environments on San Salvador Island, Bahamas. Guidebook for Geological Society of America, Orlando annual meeting field trip: Ft. Lauderdale, FL, CCFL Bahamian Field Station, pp. 1-8.

2. Teeter, J.W., 1985. Pigeon Creek Lagoon, a modern analogue of the Pleistocene Granny Lake Basin: in, Curran, H.A. (ed), Pleistocene and Holocene Carbonate Environments on San Salvador Island, Bahamas, Guidebook for Geological Society of America, Orlando annual meeting field trip: Ft. Lauderdale, FL, CCFL Bahamian Field Station, p. 147-160.

3. Sorby, H.G., 1879. The structure and origin of limestones. Proceedings of the Geological Society of London, v. 25 , p. 56-95.

4. Illing, L. V., 1954. Bahaman calcareous sands. American Association of Petroleum Geologists, Bulletin, v. 38, p. 1-95.
5. Ginsburg, R.N., 1956. Environmental relationship of grain size and constituent particles in some south Florida carbonate sediments. American Association of Petroleum Geologists, Bulletin, v. 40, p. 23842427.

6. Kornicker, L.S. and Purdy, e.g., 1957. A Bahamian fecal pellet sediment. Journal of Sedimentary Petrology, v. 27, p. 126-128.

7. Purdy, E.G., 1963a. Recent calcium carbonate facies of the Great Bahama Bank, 1, petrography and reaction groups. Journal of Geology, v. 71, p. 334-355.

8. Purdy, E. G., 1963b. Recent calcium carbonate facies of the Great Bahama Bank, 2, sedimentary facies. Journal of Geology, v. 71, p. $472-497$.

9. Folk, R.L. and Robles, R., 1964. Carbonate sands of Isla Perez, Alcaran Reef Complex, Yucatan. Journal of Geology, v. 72, p. 255-292.

10. Matthews, R.K., 1966. Genesis of recent lime mud in southern British Honduras. Journal of Sedimentary Petrology, v. 36, p. 428-454.

11. Stockman, K.W., Ginsburg, R.N., and Shinn, E.A., 1967. The production of lime mud by algae in south Florida. Journal of Sedimentary Petrology, v. 37, p. $633-648$.

12. Force, L.M., 1969. Calcium carbonate size distribution on the W. Florida shelf and experimental studies on the microarchitectural control of skeletal breakdown. Journal of Sedimentary Petrology, v. 39, p. 902-934.

13. Land, L.S., 1970. Carbonate mud: production by epibiont growth on Thallassia testudinum. Journal of Sedimentary Petrology, v. 40, p. 13611363.

14. Stieglitz, R.D., 1972 Scanning electron microscopy of the fine fraction of recent carbonate sediments from Bimini, Bahamas. Journal of Sedimentary Petrology, v. 42, p. 211226.

15. Stieglitz, R.D., 1973. Carbonate needles: additional organic sources. Geological Society of America Bulletin, v. 84, p. 927-930.

16. Neumann, A.C. and Land, L.S., 1975. Lime mud deposition and calcareous 
algae in the Bight of Abaco, Bahamas: a budget. Journal of Sedimentary Petrology, v. 45, p. 73-786.

17. Flügel, E., Microfacies Analysis of Limestone. (Springer-Verlag, New York, 1982).

18. Shinn, E.A., Steinen, R.P., Lidz, B.H. and Swart, R.K., 1989. Whitings, a sedimentologic dilemma. Journal of Sedimentary Petrology, v. 59, p. 147161.

19. Ball, M.M., Shinn, E.A., and Stockman, K.W., 1967. The geologic effects of
Hurricane Danna in South Florida. Journal of Geology, v. 75, p. 583-597.

20. Enos, P., 1983. Shelf, in, Scholle, P.A., Bebout, D.G., and Moore, C.H. (Eds), Carbonate Depositional Environments. American Association of Petroleum Geologists Memoir 33, p. 267-296.

21. Goodell, H.G. and Garman, R.K., 1969. Carbonate geochemistry of Superior deep test well, Andros Island, Bahamas. American Association of Petroleum Geologists Bulletin, v. 53, p. 513-536.

\section{College of Saint Benedict}

\section{Saint John's University}
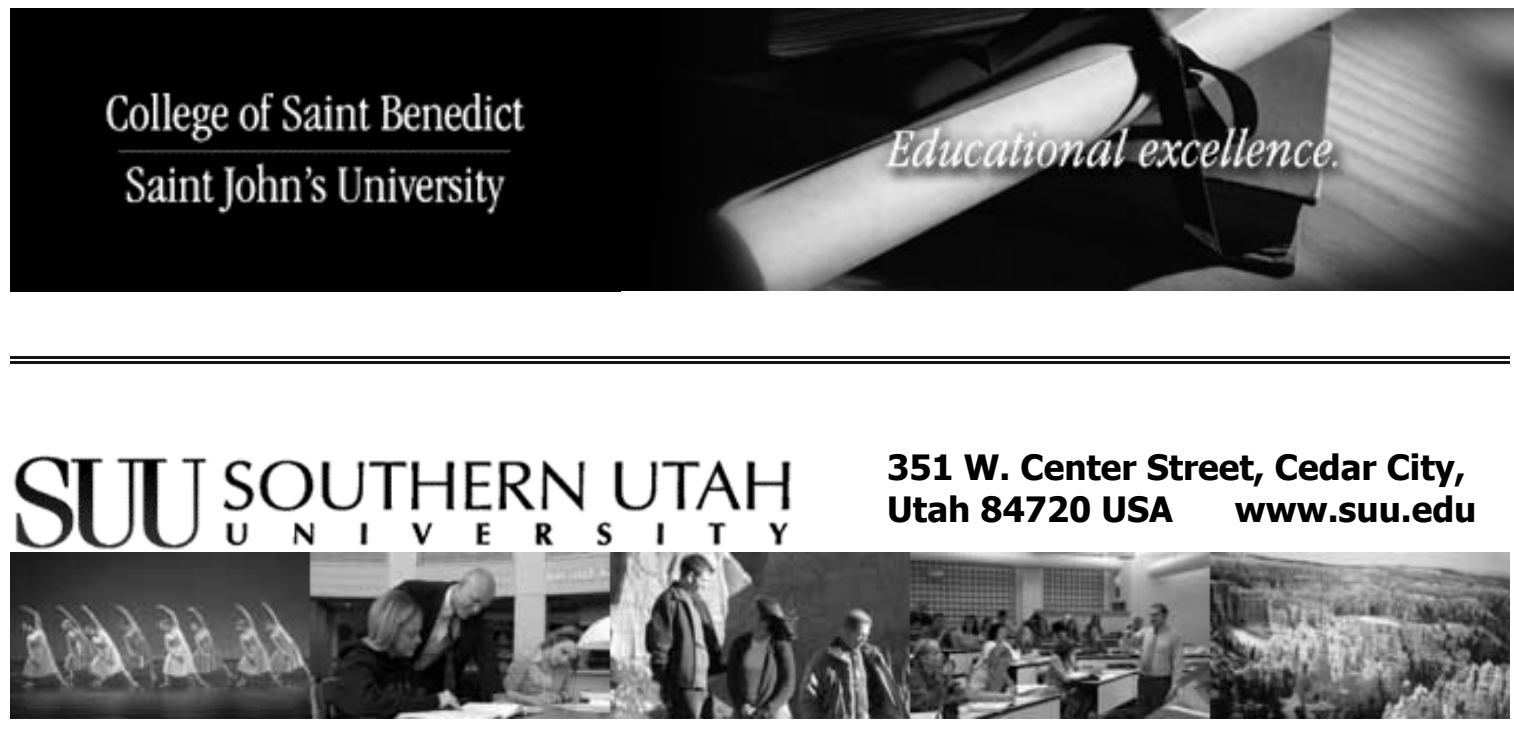

University facilities range from the ivy covered Old Main and Braithwaite Liberal Arts Center building built in 1898 and 1899 to the Dixie Leavitt Business Building to the Centrum, special events center and classroom building, the Science Center, the Gerald R. Sherratt Library and the J.L. Sorenson Physical Education Building. As the home of the Utah Shakespearean Festival, SUU also features one of the world's most authentic Shakespearean stages and the Randall L. Jones Performing Arts Theatre. In addition, the University owns and operates a 1,032-acre farm in western Cedar Valley and a 2,500acre ranch in Cedar Canyon. The ranch includes a Mountain Center for executive leadership and continuing education programs. The University's Ashcroft Observatory is located outside the lighted neighborhoods of Cedar City for better celestial viewing opportunities. Because of their proximity and grandeur, Zion National Park and Cedar Breaks National Monument are claimed by students as part of the campus. Indeed, geological and life science field trips take advantage of these national treasures. Bryce Canyon and Grand Canyon National Parks lie close by for easy touring. The University's skiing classroom is at 10,000-foot Brian Head Ski Area, less than an hour away. 